\title{
The Relationship between History of Breastfeeding and Obesity on Elementary School Children
}

\author{
David Jhon Ricardo Pakpahan ${ }^{1}$, Ika Citra Dewi Tanjung ${ }^{2}$, Haflin Soraya Hutagalung ${ }^{3}$ \\ ${ }^{I}$ Faculty of Medicine, Universitas Sumatera Utara, Medan \\ ${ }^{2}$ Department of Pediatric Health, Faculty of Medicine Universitas Sumatera Utara, Haji Adam Malik General \\ Hospital, Medan \\ ${ }^{3}$ Department of Neurology, Faculty of Medicine Universitas Sumatera Utara, Haji Adam Malik General \\ Hospital, Medan
}

\begin{abstract}
Obesity is a public health concern that its prevalence and intensity on children have been increasing with alarming status. Breastfeeding has been considered as one of protective factors that can prevent childhood obesity. The aim of this study is to discover the relationship between history of breastfeeding and obesity on elementary school children. This is an analytical study with cross sectional design. All children in first and second grade of Namira Islamic Elementary School and their mothers were included as population. Ninety samples were recruited randomly. Data on breastfeeding history were collected by using questionnaire guided interview from the mothers. The BMI-for-age curve CDC 2000 was used to determine obesity status of the children ( $\geq 95$ th percentile). Data were analyzed using chi-square test. This study found percentage of children with and without history of breastfeeding consecutively is $92.2 \%$ and $7.8 \%$. Prevalence of children with obesity is $12.2 \%$ and without obesity is $87.8 \%$. Eight of 83 children with history of breastfeeding $(72.7 \%)$ were obese, and 3 of 7 children without history of breastfeeding (27.3\%) were obese ( $\mathrm{PR}=0.2 ; 95 \% \mathrm{CI}=0.27$ $0.752 ; p<0.05)$. Based on the study, there is a relationship between history of breastfeeding and obesity in elementary school children.
\end{abstract}

\section{Keywords: Breastfeeding, Elementary School Children, Obesity}

\section{ABSTRAK}

Obesitas merupakan masalah kesehatan yang prevalensi dan intensitas kejadiannya pada anak terus meningkat serta telah mencapai status yang mengkhawatirkan. Pemberian ASI telah dipertimbangkan sebagai salah satu faktor yang dapat mencegah terjadinya obesitas pada anak. Tujuan dari penelitian ini adalah untuk mengetahui adanya hubungan antara riwayat pemberian ASI dengan kejadian obesitas pada anak sekolah dasar. Penelitian ini dilakukan melalui pendekatan analitik dengan desain cross sectional. Populasi penelitian ini adalah anak Sekolah Dasar Swasta Islam Namira yang berada di kelas satu dan dua dan Ibu nya. Jumlah sampel dalam peneltian ini adalah 90 orang yang dipilih secara acak. Data mengenai riwayat pemberian ASI didapatkan melalui wawancara dengan kuesioner dari Ibu. Kriteria obesitas pada anak ditentukan dengan menggunakan kurva indeks massa tubuh menurut usia dari CDC 2000 (persentil $\geq 95$ ). Data yang didapat dianalisis dengan uji kai kuadrat. Pada penelitian ini ditemukan 92.2\% anak mendapat ASI dan $7.8 \%$ anak tidak mendapat ASI saat bayi. Anak yang mengalami obesitas adalah $12.2 \%$ sedangkan anak yang tidak mengalami obesitas adalah $87.8 \%$. Anak yang mendapat ASI dan mengalami obesitas adalah $72.7 \%$ sedangkan anak yang tidak diberi ASI dan mengalami obesitas adalah 27.3\%. Berdasarkan hasil uji hipotesis didapatkan ( $R P=0.2$; $95 \% \mathrm{CI}=0.27-0.752: p<0.05$ ). Berdasarkan hasil penelitian didapatkan bahwa terdapat hubungan antara riwayat pemberian ASI dengan kejadian obesitas pada anak sekolah dasar.

Kata Kunci: Anak Sekolah Dasar, ASI, Obesitas 


\section{INTRODUCTION}

Obesity has been a health concern not only in well-developed, but also in developing countries. Its prevalence and intensity have been increasing with alarming status. ${ }^{[1]}$ World Health Organization (WHO) estimates that there are 42 millions obese or overweight babies and children under 5 years age in the worldwide. In Indonesia, prevalence of obesity on children ( 5 to twelve years age) is as high as $8.8 \%$. Sumatera Utara is one of provinces with higher prevalence than national, which is $10 \%$. Babies and children tend to be in obesity until adult if there is no intervention. ${ }^{[2,3]}$

Obesity and its morbidities are challenging for health care providers. This is because therapy for obesity needs long time and its cost for health problem caused by, is expensive. Therefore, preventive approach is the best solution for obesity problem, and because obesity on children is an important predictor of obesity on adult, thus the approach in childhood must be the main focus. ${ }^{[1,4]}$

Breast milk is special food resources to baby and contains all nutrition for their growth and development. These can't be replaced with other type of food, because breast milk contains antioxidant to protect them from infection. ${ }^{[5]}$

Besides, breastfeeding has been considered as one of preventive factors against obesity. The suggested mechanisms are:

1) Breastfed babies have more discretion to adjust the amount of breast milk they need to, if compared with formula-fed babies, so that there will be a better self-regulation for energy intake in the future

2) Breast milk contains lots of hormones such as leptin, ghrelin, and adiponectin that may affect body fat deposition positively

3) Formula milk, as comparison with breast milk, contains more protein that may increase adiposity and body weight among formula-fed babies. ${ }^{[6]}$

One study in Japan identified that breastfeeding has protective effect of obesity among children. ${ }^{[6]}$ However, another studies in Iran and Indonesia (Bali) identified different result, that breastfeeding has no protective effect on obesity among children. ${ }^{1}$ The difference is may be caused by different design, study samples, and control of bias factors on each studies. ${ }^{[4,7]}$

Thus, this study is made to identify whether there is a relationship between breastfeeding and obesity on elementary school children.

\section{METHOD}

\section{a. Study Design And Sampling}

This is an analytical study with cross sectional design and has been taken in Namira Islamic Elementary School. This study involved 90 students from first and second grade, including their Mothers, and recruited randomly. The aim and methods of this study were explained to the Mothers by using written explanation sheet to obtain informed consent. This study has been approved by Ethical Committee of Faculty of Medicine University of Sumatera Utara.

\section{b. Respondent Characteristics and History of Breastfeeding}

Respondent characteristics (Mothers and children) and history of breastfeeding were obtained by using questionnaire guided interview. Respondent characteristics consist of children age and gender, and Mother's education. History of breastfeeding consists of questions about whether children had breastfed and breastfed exclusively when they were babies. Exclusive breastfeeding is defined as giving breast milk only without any foods or drinks even water (except drugs) until six months of age. In addition, 
history of formula feeding was included in the questionnaire.

\section{c. Nutritional Status Measurement}

Children's Body Mass Index (BMI) were obtained by calculating body weights and heights $\left(\mathrm{kg} / \mathrm{m}^{2}\right)$. Then, the BMI results projected to BMI -for age curve from Center of Disease Control and Prevention (CDC) 2000 to determine children's nutritional status. Nutritional status were divided to 2 main categories as obesity (BMI $\geq 95^{\text {th }}$ percentiles), and non-obesity (overweight, BMI $85^{\text {th }}-94^{\text {th }}$ percentiles; normoweight, BMI $5^{\text {th- }} 84^{\text {th }}$ percentiles; and underweight, $\mathrm{BMI}<5^{\text {th }}$ percentiles).

\section{d. Statistical Analysis}

Respondent characteristics, history of breastfeeding, and children's nutritional status were determined with descriptive statistic. The relationship between history of breastfeeding and children's nutritional status (obesity and non-obesity) were tested with chi-square test. $\mathrm{P}$ value $<0.05$ was considered as the level of statistical significance.

\begin{tabular}{ccc}
\multicolumn{3}{c}{ RESULT } \\
Table 1 & shows & respondent \\
characteristics, & children's & nutritional
\end{tabular}
status, and history of breastfeeding. A total number of 90 children (and their Mothers) were recruited in this study; $40 \%$ were boys and $60 \%$ were girls. The highest percentage of children was aged 6 , which is $51.1 \%$. And the highest percentage of Mother's education was Bachelor's, which is $47.8 \%$

Prevalence of obesity among children in this study is $12.2 \%$. The majority of children $(92,2 \%)$ were breastfed during baby. However, exclusive breastfed children were only $12.2 \%$. Formula-fed children, either on breast-fed or not breastfed, were $68.9 \%$.
Table 1. Respondent characteristics and bistory of breastfeeding

\begin{tabular}{|c|c|}
\hline $\begin{array}{l}\text { Respondent } \\
\text { Characteristics }\end{array}$ & $\begin{array}{c}\begin{array}{c}\text { Respondent } \\
n=90\end{array}\end{array}$ \\
\hline \multicolumn{2}{|l|}{ Age in Years, $\mathrm{n}(\%)$} \\
\hline 5 & $1(1.1)$ \\
\hline 6 & $46(51.1)$ \\
\hline 7 & $41(45.6)$ \\
\hline 8 & $2(2.2)$ \\
\hline \multicolumn{2}{|l|}{ Sex, n (\%) } \\
\hline Boy & $36(40.0)$ \\
\hline Girl & $54(60.0)$ \\
\hline \multicolumn{2}{|l|}{ Nutritional Status, n (\%) } \\
\hline Obesity & $11(12.2)$ \\
\hline Non-Obesity & $79(87.8)$ \\
\hline • Overweight & $8 \quad(8.9)$ \\
\hline - Normoweight & $\begin{array}{ll}56 & 62.2)\end{array}$ \\
\hline • Underweight & $15(16.7)$ \\
\hline \multicolumn{2}{|l|}{$\begin{array}{l}\text { Mother's Education, } \\
\mathrm{n}(\%)\end{array}$} \\
\hline Junior High & $2(2.2)$ \\
\hline Senior High & $27(30)$ \\
\hline Associate Degree-1 & $1(1.1)$ \\
\hline Associate Degree-2 & $14(15.6)$ \\
\hline Bachelor's Degree & $43(47.8)$ \\
\hline Master's Degree & $2(2.2)$ \\
\hline Doctoral Degree & $1(1.1)$ \\
\hline History & \\
\hline \multicolumn{2}{|l|}{ Breastfeeding, n (\%) } \\
\hline Yes & $83(92.2)$ \\
\hline No & $7(7.8)$ \\
\hline \multicolumn{2}{|l|}{ History of Exclusive } \\
\hline \multicolumn{2}{|l|}{ Breastfeeding, $\mathrm{n}(\%)$} \\
\hline Yes & $19(21.1)$ \\
\hline No & $71(78.9)$ \\
\hline History of Formula & \\
\hline \multicolumn{2}{|l|}{ Feeding, $\mathrm{n}(\%)$} \\
\hline Yes & $62(68.9)$ \\
\hline No & $28(31.1)$ \\
\hline
\end{tabular}

Table 2 shows percentage of obesity based on history of breastfeeding (including those who has history of breastfeeding and formula feeding simultaneously) and its relationship statistically. Percentage of obesity among breastfed is higher than among not breastfed children during baby, which is $72,7 \%$. Yet, percentage of obesity among exclusively breastfed is lower than among not exclusively breastfed children, which is $12.5 \%$. Based on Fisher's exact test, there is significant relationship between 
history of breastfeeding and obesity $(p=0.037 ; \quad O R=0.142 ; \quad C I=0.027-0.752)$, whereas history of exclusive breastfeeding and obesity has no significant relationship among elementary school children $(\mathrm{p}=0.67 ; \mathrm{OR}=0.452 ; \mathrm{CI}=0.052-3.92)$.

Table 2. Relationship between history of breastfeeding and obesity

\begin{tabular}{lcccc}
\hline History of Breastfeeding & $\begin{array}{c}\text { Obesity } \\
\mathbf{n}(\%)\end{array}$ & $\begin{array}{c}\text { Non-obesity } \\
\mathbf{n}(\%)\end{array}$ & PR (95\% CI) & P value \\
\hline Breastfeeding & & & & \\
$\quad$ Yes & $8(72.7)$ & $75(94.9)$ & $0.142(0.027-$ & 0.037 \\
$\quad$ No & $3(27.3)$ & $4(5.1)$ & $0.752)$ & \\
Exclusive Breastfeeding & & & & \\
$\quad$ Yes & $1(12.5)$ & $18(24)$ & $0.452(0.052-$ & 0.675 \\
$\quad$ No & $7(87.5)$ & $57(76)$ & $3.928)$ & \\
\hline
\end{tabular}

Not only based on history of breastfeeding, this study is also shows obesity incidence through the history of formula feeding. Table 3 shows the higher percentage of obesity among children with history of formula feeding $(81.8 \%)$ than among children without history of formula feeding (18.2\%) during baby.

Table 3. Percentage of obesity incidences based on history of formula feeding

\begin{tabular}{lcc}
$\begin{array}{l}\text { History of } \\
\text { Formula } \\
\text { Feeding }\end{array}$ & $\begin{array}{c}\text { Obesity } \\
\text { n (\%) }\end{array}$ & $\begin{array}{c}\text { Non-Obesity } \\
\mathbf{n}(\%)\end{array}$ \\
\hline $\begin{array}{l}\text { Formula } \\
\text { Feeding }\end{array}$ & & \\
$\quad$ Yes & $9(81.8)$ & $53(67.1)$ \\
$\quad$ No & $2(18.2)$ & $26(32.9)$ \\
\hline
\end{tabular}

\section{DISCUSSION}

This study involved 90 respondents as samples. Based on table 1 of this study, there is bigger proportion on breastfed than not breastfed respondents as $92.2 \%$ and consistent with previous study in Brazil with $92.6 \%{ }^{[4]}$

This study also showed smaller proportion of exclusively breastfed than not exclusively breastfed respondents, which is $21.1 \%$. The result is not consistent with Demographic and Health Survey (DHS) Indonesia 2012, that proportion of exclusively breastfed children is $41 \%{ }^{[8]}$ It is caused by combination between breastfeeding and formula feeding. ${ }^{[9]} \quad$ Furthermore, respondents of this study probably don't know how to breastfeed exclusively well. Based on this study, we found that the prevalence of obesity among elementary school children is very high as $12.2 \%$ and consistent with data from Riset Kesehatan Dasar (Riskesdas) Indonesia 2013 as $10 \%{ }^{[3]}$

Apart from it, this study also identified the highest incidence of obesity among breastfed (including those who breastfed and formula-fed simultaneously) compared than not breastfed respondents as $72.7 \%$ and is consistent with previous study in Brazil where the incidence of obesity among breastfed respondents as $89 \%{ }^{\left[{ }^{[4]}\right.}$ Yet, it's contradictory with one study in Indonesia (Bali) that the highest incidence of obesity among not breastfed respondents is $71 \% .{ }^{[7]}$ The explanation is because there is history of early complementary feeding to study respondents. Besides, there were no adjustments for other variables that can affect obesity such as genetic (parents' nutritional status), diet, and physical activities in this study.

The result of Fisher's exact test showed there is significant relationship between history of breastfeeding and obesity among elementary school children with $p=0.037 \quad(p<0.05)$. This result is similar with previous studies in Ireland $(p=0.010)$, Australia $(p=0.009)$, and United States of America $(p=0.001) .{ }^{[10-12]}$

This study identified Prevalence Ratio $(\mathrm{PR})=0.2$ and showed breast milk as a 
protective factor for obesity among children. The protective effect is consistent with many previous studies about the benefits of breast milk against obesity. Breast milk prevents early complementary feeding with high fat and sugar food products. Breastfed children tend to have better regulation to appetite compared to formula fed children so that reducing the possibility of unhealthy weight gain. ${ }^{[12]}$ The mechanism is strengthen with various bioactive component in breast milk such as, leptin and ghrelin to set up hunger. ${ }^{[10]}$

This study found the highest incidence of obesity among exclusively breastfed children compared to those who are not exclusively breastfed children as $87.5 \%$ and consistent with previous study in Indonesia (Semarang) as 78.6\%. ${ }^{[13]}$

Based on Fisher's exact test, there is no significant relationship between history of exclusive breastfeeding with obesity among elementary school children $(p=0.675)$ and similar with previous study in Indonesia (Bali) with $p=0.537 .{ }^{[7]}$ Nonetheless, the $\mathrm{PR}=0.5$ and showed exclusive breastfeeding as protective factor against obesity among children with explained mechanisms.

This study also identified the highest incidence of obesity among formula fed children (both combination with breast milk or not), which is $81.8 \%$. It's similar with one previous study in Canada $(90.6 \%) .{ }^{[14]}$ The amount of protein in formula milk is higher (compared to in breast milk) and play an important role to obesity in children. ${ }^{[15]}$

Besides history of breastfeeding, there are many factors that can affect obesity among children, such as genetic and physical activities. ${ }^{[4,7]}$

\section{CONCLUSION}

The prevalence of obesity among elementary school children in North Sumatera is high. The history of breastfeeding has significant relationship to obesity among elementary school children and can be considered as an effort to encounter obesity problems.

\section{LIMITATION}

This study has several limitations that can affect the study results. First, this study has no adjustment to other variables that can affect obesity (such as diet, physical activities, and parents' obesity status). Second, there is recalling bias while answering the history of breastfeeding during baby by the Mothers.

\section{REFERENCES}

[1] Vafa M, Moslehi N, Afshari S, Hossini A, Eshraghian M. Relationship between breastfeeding and obesity in childhood. $J$ Health Popul Nutr. 2012 Sep;30(3):30310.

[2] World Health Organization. Facts and figures on childhood obesity. [internet]. 2014; [dikutip pada 2016 April 10]. Diakses dari: http://www.who.int/endchildhood-obesity/facts/en/

[3] Badan Penelitian dan Pengembangan Kesehatan Kementerian Kesehatan RI. Riset Kesehatan Dasar (Riskesdas) 2013.

[4] Novaes JF, Lamounier JA, Colosimo EA, Franceschini SC, Priore SE. Breastfeeding and obesity in Brazilian children. Eur $J$ Public Health. 2011 May;22(3):383-9.

[5] Alimoradi F, Javadi M, Barikani A, Kalantari N, Ahmadi M. An overview of importance of breastfeeding. $J$ Compr Ped. 2014 May;5(2):e14028.

[6] Yamakawa M, Yorifuji T, Inoue S, Kato T, Doi H. Breastfeeding and obesity Among schoolchildren a nationwide longitudinal survey in Japan. JAMA Pediatr. 2013;167(10):919-25.

[7] Satyawati PA. Sidiartha IGL. Hubungan riwayat pemberian ASI dan durasi pemberian ASI dengan kejadian obesitas pada anak sekolah dasar. [skripsi] Denpasar: Universitas Udayana; 2015.

[8] Badan Kependudukan dan Keluarga Berencana Nasional, Badan Pusat Statistik, Kementerian Kesehatan RI. Survei Demografi dan Kesehatan Indonesia 2012. 
[9] Escribano J, Luque V, Ferre N, MendezRiera G, Koletzko B, Grote V, dkk. Effect of protein intake and weight gain velocity on body fat mass at 6 months of age: The EU Childhood Obesity Programme. Int J Obesity. 2012 Feb;36:548-553.

[10] McCrory C, Layte R. Breastfeeding and risk of overweight and obesity at nineyears of age. Soc Sci Med. 2012;72:323330.

[11] Scott JA, Ng SY, Cobiac L. The relationship between breastfeeding and weight status in a national sample of Australian children and adolescent. BMC Public Health. 2012;12:107-112.

[12] Moss BG, Yeaton WH. Early childhood healthy and obese weight status: potentially protective benefits of breastfeeding and delaying solid foods. Matern Child Health J. 2013;18:12241232.

[13] Saputri EL. Hubungan riwayat pemberian ASI eksklusif dengan kejadian obesitas pada anak usia 4-5 tahun. [skripsi] Semarang: Universitas Diponegoro; 2013.

[14] Rossiter MD, Colapinto CK. Khan MKA, McIsaac JLD. Williams PL, Kirk SFL, dkk. Breast, formula and combination feeding in relation to childhood obesity in Nova Scotia, Canada. Matern Child Health J. 2015 Sep;19(9):2048-56.

[15] Holmes AV, Auinger P, Howard CR. Combination feeding of breast milk and formula: Evidence for shorter breastfeeding duration from the National Health and Nutrition Examination Survey. J Pediatr. 2011 Aug;159(2):186-191. 